\title{
EFFICACY OF DASHANG LEPA IN THE MANAGEMENT OF VRANASHOPHA (CELLULITIS): A PRELIMINARY CLINICAL STUDY
}

\author{
Research Article
}

\begin{tabular}{c}
\hline Soni Ashish ${ }^{\mathbf{1}^{*}},{\text { Gupta S. } \mathbf{J}^{\mathbf{2}}}^{\text {1. JR III, 2. Assistant Professor, Department of Shalya Tantra, }}$ \\
Faculty of Ayurveda, IMS, Banaras Hindu University, Varanasi (U.P). \\
\hline
\end{tabular}

\begin{abstract}
Acharya Sushruta has mentioned a detail description of inflammatory swelling under the heading of Vranashopha. Clinical features of Vranashopha are much resembled to inflammatory swelling like as cellulitis. Cellulitis can cause mild discomfort to severe toxaemia, which can lead to death. In such condition, only systemic drugs are in clinical use, but they are not much helpful to eradicate the acute problem. It is probably, due to lack of their local availability on the swollen area, which further leads to ischemia cell death and ultimately gangrene formation. In this way we hypothesize that drugs, which could reduce local swelling/tissue damage, may be helpful in management of inflammation. Dashang lepa (mixture of ten indigenous drugs) mixed with $1 / 5^{\text {th }}$ part of pure cow's ghrita (butter) was taken for external application over Vranashopha (cellulitis) in trial group. Clinical study in 20 patients of cellulitis in respect of local and generalized criteria was done. In the study, group containing Dashang lepa showed statistically highly significant $(<0.01)$ in terms of reduction of pain, edema, erythema, tenderness and fever in the patients of cellulitis. Thus results revealed Dashang lepa is very effective against superficial inflammatory swelling.
\end{abstract}

Key words: Acharya Sushruta, Vranashopha, Cellulitis, Inflammation, Dashang lepa, Ghrita

\section{Introduction:}

Acharya Sushruta, father of Indian surgery (Shalya Tantra) was well aware of importance of Vranashopha (inflammatory swelling) and Vrana (wound) and their management in surgical practice. The Vranashopha was described as earlier phase of Vrana (1).

Clinical features of Vranashopha told by Acharya Sushruta very much

\footnotetext{
*Corresponding Author:

Soni Ashish,

JR III, Department of Shalya Tantra,

Faculty of Ayurveda, IMS, Banaras Hindu

University, Varanasi (U.P).

E-mail: dr.ashishsoni84@gmail.com.

Phone: +91 8765000669
}

resembles inflammatory swelling like as cellulitis. Cellulitis is characterised by an acute, diffuse, spreading, oedematous non suppurative inflammation of the dermis and subcutaneous tissues (2). Cellulitis can cause mild discomfort to severe complications like sepsis, local gangrene, necrotising fasciitis, septicaemia which can lead to death (3). Condition of necrotising fasciitis is very dangerous which has $39 \%$ of mortality rate (4). So it is necessary to prevent spreading inflammation in primary condition and save more hazardous complications in health system. Though there are several systemic anti-microbial drugs are available for management of the problem but these are not sufficient to eradicate the acute 
problem completely and have their own limitations. In that way, external (local) application of some herbal drug formulation over cellulitis can also prove better to manage the disease. Dashang lepa (mixture of ten indigenous drugs) mixed with $1 / 5^{\text {th }}$ part of pure cow's ghrita (butter) was selected for external application over Vranashopha (cellulitis) in trial group. Ointment Su-mag (i.e. combination of dried magnesium sulphate $58 \%$, urea $1 \%$, sulphacetamide sodium $2.5 \%$, proflavine and glycerine) was advised in control group. This clinical study was done in 20 patients of cellulitis in the Department of Shalya Tantra, Faculty of Ayurveda, Institute of Medical Sciences, Banaras Hindu University, Varanasi.

\section{Material and Method:}

Dashang lepa is a powdered form herbal preparation made by ten indigenous drugs. These drugs and their properties with useful part are given in table no. 1

Table: 1 Contents of Dashang lepa and their Properties

\begin{tabular}{|c|c|c|c|c|c|c|}
\hline Plant & $\begin{array}{c}\text { Rasa } \\
\text { (Taste) }\end{array}$ & $\begin{array}{c}\text { Guna } \\
\text { (Physical } \\
\text { properties } \\
\text { ) }\end{array}$ & $\begin{array}{c}\text { Virya } \\
\text { (Potency } \\
\text { ) }\end{array}$ & $\begin{array}{c}\text { Vipaka } \\
\text { (Outcom } \\
\text { e after } \\
\text { digestion } \\
\text { ) }\end{array}$ & $\begin{array}{c}\text { Dosh karma } \\
\text { (Effect on } \\
\text { doshas) }\end{array}$ & $\begin{array}{c}\text { Useful } \\
\text { part }\end{array}$ \\
\hline $\begin{array}{l}\text { 1.Shirish } \\
\text { (Albizzia } \\
\text { lebbeck Benth.) }\end{array}$ & Kashaya & $\begin{array}{l}\text { Laghu, } \\
\text { Ruksha }\end{array}$ & $\begin{array}{l}\text { Ishad- } \\
\text { Ushna }\end{array}$ & Katu & $\begin{array}{c}\text { Tridoshahar } \\
\qquad a\end{array}$ & Bark \\
\hline $\begin{array}{l}\text { 2.Madhuyasthi } \\
\text { (Glycyrrhiza } \\
\text { glabra Linn.) }\end{array}$ & Madhura & $\begin{array}{c}\text { Guru, } \\
\text { Snigdha }\end{array}$ & Sheeta & Madhura & $\begin{array}{c}\text { Vata- } \\
\text { Pittashamak }\end{array}$ & Root \\
\hline $\begin{array}{l}\text { 3.Tagar } \\
\text { (Valeriana } \\
\text { wallichii DC.) }\end{array}$ & $\begin{array}{c}\text { Tikta,Katu } \\
\text { Kashaya }\end{array}$ & $\begin{array}{l}\text { Laghu, } \\
\text { Snigdha }\end{array}$ & Ushna & Katu & $\begin{array}{c}\text { Kapha- } \\
\text { Vatashamak }\end{array}$ & Root \\
\hline $\begin{array}{l}\text { 4.Raktachanda } \\
\text { n (Pterocarpus } \\
\text { santalinus } \\
\text { Linn.) }\end{array}$ & $\begin{array}{c}\text { Tikta, } \\
\text { Madhura }\end{array}$ & $\begin{array}{l}\text { Guru, } \\
\text { Ruksha }\end{array}$ & Sheeta & Katu & $\begin{array}{c}\text { Kapha-Pitta } \\
\text { shamak }\end{array}$ & $\begin{array}{c}\text { Heartwoo } \\
\text { d }\end{array}$ \\
\hline $\begin{array}{l}\text { 5.Ela (Eletteria } \\
\text { cardamomum } \\
\text { Linn. Maton) }\end{array}$ & $\begin{array}{c}\text { Katu, } \\
\text { Madhura }\end{array}$ & $\begin{array}{l}\text { Laghu, } \\
\text { Ruksha }\end{array}$ & Sheeta & Madhura & $\begin{array}{c}\text { Tridoshahar } \\
\qquad a\end{array}$ & Fruit-Seed \\
\hline $\begin{array}{l}\text { 6.Jatamansi } \\
\text { (Nardostachys } \\
\text { jatamansi DC.) }\end{array}$ & $\begin{array}{c}\text { Tikta, } \\
\text { Kashaya, } \\
\text { Madhura }\end{array}$ & $\begin{array}{c}\text { Laghu, } \\
\text { Snigdha, } \\
\text { Tikshna }\end{array}$ & Sheeta & Katu & $\begin{array}{c}\text { Kapha- } \\
\text { Pittashamak }\end{array}$ & Rhizome \\
\hline $\begin{array}{l}\text { 7.Haridra } \\
\text { (Curcuma } \\
\text { longa Linn.) }\end{array}$ & $\begin{array}{l}\text { Tikta, } \\
\text { Katu }\end{array}$ & $\begin{array}{l}\text { Laghu, } \\
\text { Ruksha }\end{array}$ & Ushna & Katu & $\begin{array}{c}\text { Kapha-Vata } \\
\text { shamak, } \\
\text { Pittarechak }\end{array}$ & Rhizome \\
\hline $\begin{array}{l}\text { 8.Daruharidra } \\
\text { (Berberis } \\
\text { aristata } \text { DC.) }\end{array}$ & $\begin{array}{c}\text { Tikta, } \\
\text { Kashaya }\end{array}$ & $\begin{array}{l}\text { Laghu, } \\
\text { Ruksha }\end{array}$ & Ushna & Katu & $\begin{array}{c}\text { Kapha-Vata } \\
\text { shamak, }\end{array}$ & $\begin{array}{c}\text { Root } \\
\text { Rasanjana } \\
,\end{array}$ \\
\hline $\begin{array}{l}\text { 9.Kushta } \\
\text { (Saussurea } \\
\text { lappa } \\
\text { C.B.Clarke) }\end{array}$ & $\begin{array}{l}\text { Tikta, } \\
\text { Katu }\end{array}$ & $\begin{array}{l}\text { Laghu, } \\
\text { Ruksha }\end{array}$ & Ushna & Katu & $\begin{array}{c}\text { Kapha-Vata } \\
\text { shamak }\end{array}$ & Root \\
\hline
\end{tabular}




\begin{tabular}{|l|c|c|c|c|c|c|}
\hline $\begin{array}{l}\text { 10.Hrivera } \\
\text { (Pavonia } \\
\text { odorata Willd.) }\end{array}$ & $\begin{array}{c}\text { Tikta,Katu } \\
\text { Kashaya }\end{array}$ & $\begin{array}{l}\text { Laghu, } \\
\text { Snigdha }\end{array}$ & Sheeta & Katu & $\begin{array}{c}\text { Kapha- } \\
\text { Vatashamak } \\
\text { a }\end{array}$ & Root \\
\hline
\end{tabular}

Dashang lepa is mentioned in many Ayurvedic texts $(5,6,7,8,9)$ and described as Vranasophaghna (antiinflammatory) remedy for local application. Some plants of Dashang lepa were collected from periphery of Varanasi and some were obtained from local market. All the plants were perfectly identified with the help of Department of Dravyaguna, Faculty of Ayurveda, IMS, BHU. All 10 drugs were taken in equal amount and thoroughly washed in running tap water and dried in the natural shade at about $26^{\circ} \mathrm{C}$ Temperature. Completely dried drugs were grinded in a mixer and obtained powder was filtered through the sieve no. 85. The fine powder was kept in a dry and air tight container. Dashang lepa is mixed with Cow's pure ghrita in 5:1 ratio for local application.

After detailed clinical history and informed consent 24 patients with sign and symptom of cellulitis were registered as per designed proforma from the OPD/IPD of the Department of Shalya Tantra, Sir Sunderlal hospital I.M.S., B.H.U., Varanasi (U.P.). Random selection was made irrespective of age, sex, occupation, duration of disease, economic status etc. Out of these 20 patients could complete the study and 4 patients discontinued the treatment so they were not included in the study. Routine and needful investigation such as CBC, Blood sugar, RFT, LFT, HIV, HBsAg, had been done.

\section{Inclusion Criteria:}

Cellulitis of all parts of body except orbital cellulitis, with sign and symptoms as pain, tenderness, edema, erythema, local temperature and fever were included.

\section{Exclusion criteria:}

Patients of Diabetes mellitus, Hypertension, Chronic Renal Failure, Malignancy, Orbital cellulitis, HBsAg positive, HIV positive were excluded from the study.

\section{Assessment Criteria for cellulitis:}

Local: Local criteria as colour (erythema), edema, temperature, induration, tenderness were assessed by different grading system in the patient with cellulitis. Mild, moderate and severe grading were done according to standard protocol.

Generalised: Generalised criteria as general condition, pulse rate, blood pressure, respiration rate, pain, fever were assessed.

Investigation: Investigation as TLC (Total Leukocyte Count), DLC (Differentiate Leukocyte Count), ESR (Erythrocyte Sedimentation Rate) were selected for assessment.

Local and generalised criteria were assessed daily and investigation criteria were assessed weekly and grading of the criteria was done according to designed proforma.

Statistical analysis: Mean and Standard deviations (SD) of all variable calculated. Within the group paired t-test was done of all groups and $t$ and $p$ value was calculated (10).

\section{Plan of study:}

Patient with sign and symptom of cellulitis were divided in two groups on basis of Total Leucocyte Count [TLC];

1. Group I- In this group 10 patients with $<15,000$ cells $/ \mathrm{mm}^{3}$ TLC were registered. These were further divided in sub group: A. Control -5 patients of control group were treated by local 
application of ointment Su-mag B. Trial - 5 patients of trial group were treated by local application of Dashang Lepa. No antibiotic was given in this group.

2. Group II- In this group 10 patients with $>15,000$ cells $/ \mathrm{mm}^{3}$ TLC were registered. These were further divided in sub group: A. Control - 5 patients of control group were treated with Antibiotic Inj. Ceftriaxone and Sulbactum in dose 1.5 gm I.V. B.D. in adult with local application of ointment Su-mag. B. Trial -5 patients of trial group were treated with Antibiotic Inj. Ceftriaxone and Sulbactum I.V. in dose 1.5 gm I.V. B.D in adult with local application of Dashang lepa. Total duration of treatment were given as per require. But for clinical study the data were collected and analysed for 15 days at the interval of 5 days for three successive follow-ups.

\section{Results:}

- Out of 20 patient $70 \%$ were male and prevalence of cellulitis was found maximum $35 \%$ in age group between 41-50 years. Incidence of disease was found more in farmers. Maximum 50\% patients were of Pitta dominant prakriti. Lower extremity was found most common anatomical site of cellulitis infection which comprised $65 \%$ of total patients. The outcome was considered as $20 \%$ patients were got suppuration and $80 \%$ were got resolution of inflammation.

- Pain experienced by patients before treatment and during three successive follow-ups was estimated and paired t-test was applied for $\mathrm{t}$ and $\mathrm{p}$ value. The mean of pain before treatment was 2.80, $3.00,2.80,3.00$ in group IA, IB, IIA, IIB respectively and in third follow up it was $1.60,1.00,1.00$, 0.00 in group IA, IB, IIA, IIB respectively. Group IB and IIB were statistically highly significant $(p<0.01)$ in terms of reduction of pain.

- The mean of edema before treatment was same 3.00 in all groups but in third follow up (F3) it was $2.00,0.60,0.80,0.20$ in group IA, IB, IIA, IIB respectively. Group IB, IIA, IIB were statistically highly significant $(p<0.001)$ in terms of reduction in edema.

- The mean of tenderness before treatment was 2.6, 3.0, 2.6, 2.8 in group IA, IB, IIA, IIB respectively and in third follow up it was is 1.4, $0.6,1.2,0.2$ in group IA, IB, IIA, IIB respectively.

- The mean of erythema before treatment was 2.2, 2.8, 2.4, 3.0 and in third follow up it was 1.6, 0.6, $1.0,0.2$ in group IA, IB, IIA, IIB respectively. Group IB and IIB were statistically highly significant $(p<0.001)$ in terms of reduction in erythema.

- The mean of fever before treatment was $2.2,2.8,2.4,2.4$ and in third follow up it was $1.4,0.8,0.4,0.0$ in group IA, IB, IIA, IIB respectively. Group IA was statistically significant $(\mathrm{p}<0.05)$ and Group IB and II (A \& B) were statistically highly significant $(p<0.01)$ in terms of fever. 
Table: 2 Statistical analysis of Pain before and after treatment in all groups

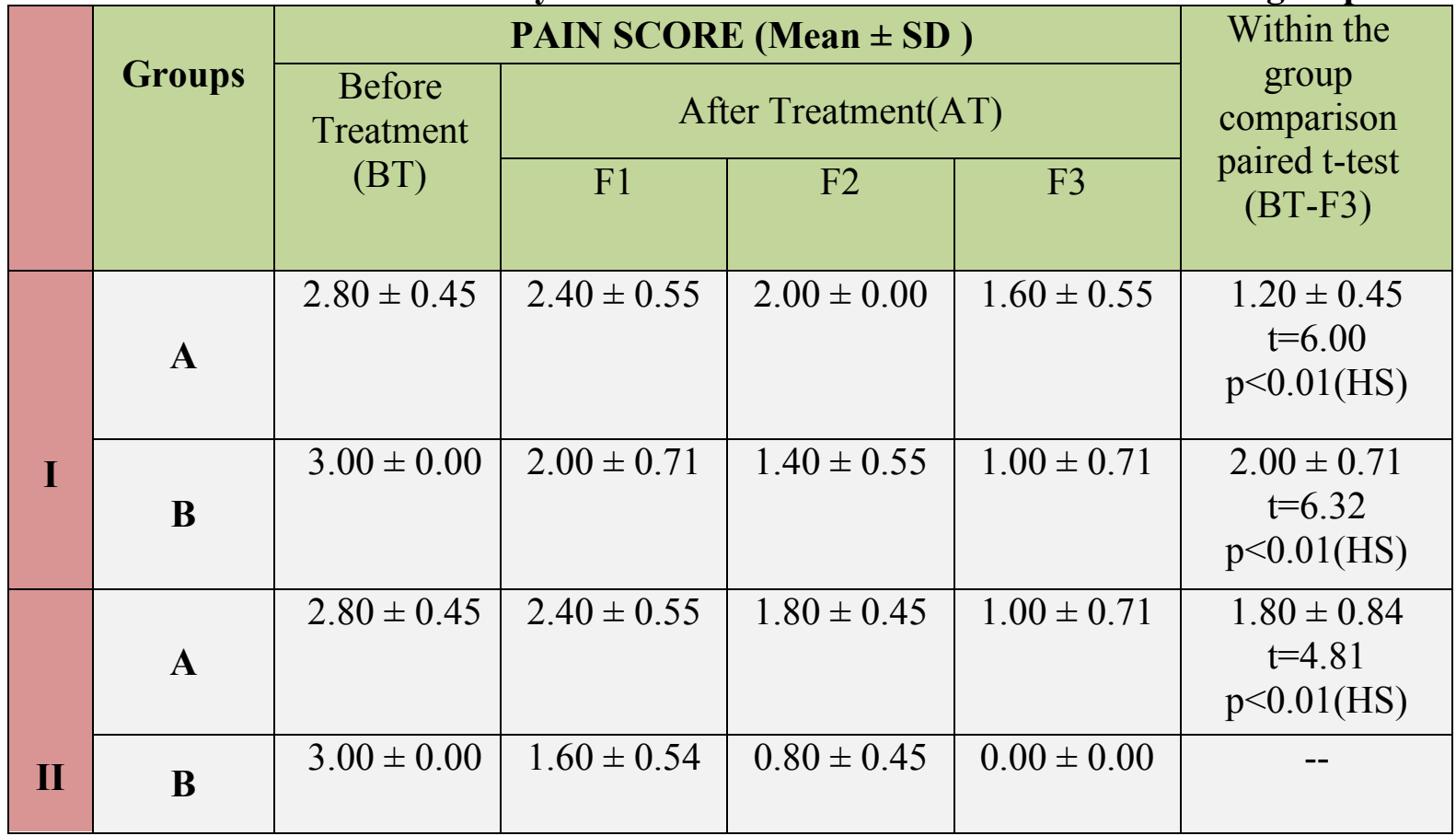

(SD- Standard Deviation, F1- First follow up, F2- Second follow up, F3- Third follow up, HS-Highly Significant)

Table: 3 Statistical analysis of Edema before and after treatment in all groups

\begin{tabular}{|c|c|c|c|c|c|c|}
\hline & & & EDEMA SC & RE (Mean \pm & D ) & \\
\hline & Group & Before & & r Treatment & & $\begin{array}{l}\text { comparison } \\
\text { paired t-test (BT- }\end{array}$ \\
\hline & & (BT) & F1 & F2 & F3 & 3) \\
\hline I & $\mathbf{A}$ & $3.00 \pm 0.00$ & $2.40 \pm 0.55$ & $2.20 \pm 0.45$ & $2.00 \pm 0.71$ & $\begin{array}{c}1.00 \pm 0.71 \\
t=3.16 \\
p<0.05(S)\end{array}$ \\
\hline & B & $3.00 \pm 0.00$ & $1.40 \pm 0.55$ & $1.00 \pm 0.71$ & $0.60 \pm 0.55$ & $\begin{array}{c}2.40 \pm 0.55 \\
t=9.79 \\
p<0.001(H S)\end{array}$ \\
\hline II & $\mathbf{A}$ & $3.00 \pm 0.00$ & $2.00 \pm 0.71$ & $1.40 \pm 0.55$ & $0.80 \pm 0.84$ & $\begin{array}{c}2.20 \pm 0.84 \\
t=5.88 \\
p<0.01(\mathrm{HS})\end{array}$ \\
\hline & B & $3.00 \pm 0.00$ & $1.20 \pm 0.45$ & $0.60 \pm 0.55$ & $0.20 \pm 0.45$ & $\begin{array}{c}2.80 \pm 0.45 \\
t=14.00 \\
p<0.001(H S)\end{array}$ \\
\hline
\end{tabular}

(S- Significant) 
Table: 4 Statistical analysis of Tenderness before and after treatment

\begin{tabular}{|c|c|c|c|c|c|c|}
\hline \multicolumn{7}{|c|}{ TENDERNESS SCORE (Mean \pm SD) } \\
\hline & \multirow{2}{*}{ Group } & \multirow{2}{*}{$\begin{array}{l}\text { Before } \\
\text { Treatment } \\
\text { (BT) }\end{array}$} & \multicolumn{3}{|c|}{ After Treatment(AT) } & \multirow{2}{*}{$\begin{array}{l}\text { Within the } \\
\text { group } \\
\text { comparison } \\
\text { paired t-test } \\
\text { (BT-F3) }\end{array}$} \\
\hline & & & F1 & $\mathrm{F} 2$ & F3 & \\
\hline \multirow[t]{2}{*}{$\mathbf{I}$} & $\mathbf{A}$ & $2.60 \pm 0.89$ & $2.00 \pm 0.71$ & $1.60 \pm 0.89$ & $1.40 \pm 0.89$ & $\begin{array}{c}1.20 \pm 0.45 \\
\mathrm{t}=6.00 \\
\mathrm{p}<0.01(\mathrm{HS})\end{array}$ \\
\hline & B & $3.00 \pm 0.00$ & $1.60 \pm 0.55$ & $0.80 \pm 0.45$ & $0.60 \pm 0.55$ & $\begin{array}{c}2.40 \pm 0.55 \\
t=9.80 \\
p<0.001(\mathrm{HS})\end{array}$ \\
\hline \multirow[t]{2}{*}{ II } & $\mathbf{A}$ & $2.60 \pm 0.55$ & $2.00 \pm 0.00$ & $1.80 \pm 0.45$ & $1.20 \pm 0.45$ & $\begin{array}{c}1.40 \pm 0.55 \\
t=5.72 \\
p<0.01(\mathrm{HS})\end{array}$ \\
\hline & B & $2.80 \pm 0.45$ & $1.40 \pm 0.55$ & $0.60 \pm 0.55$ & $0.20 \pm 0.45$ & $\begin{array}{c}2.60 \pm 0.55 \\
t=10.61 \\
p<0.001(\mathrm{HS})\end{array}$ \\
\hline
\end{tabular}

Table: 5 Statistical analysis of Erythema before and after treatment

\begin{tabular}{|c|c|c|c|c|c|c|}
\hline \multicolumn{7}{|c|}{ ERYTHEMA SCORE (Mean \pm SD) } \\
\hline & \multirow{2}{*}{ Groups } & \multirow{2}{*}{$\begin{array}{l}\text { Before } \\
\text { Treatment } \\
\text { (BT) }\end{array}$} & \multicolumn{3}{|c|}{ After Treatment(AT) } & \multirow{2}{*}{$\begin{array}{l}\text { Within the } \\
\text { group } \\
\text { comparison } \\
\text { paired t-test } \\
\text { (BT-F3) }\end{array}$} \\
\hline & & & F1 & $\mathrm{F} 2$ & F3 & \\
\hline \multirow[t]{2}{*}{$\mathbf{I}$} & $\mathbf{A}$ & $2.20 \pm 0.84$ & $2.00 \pm 0.71$ & $1.80 \pm 0.45$ & $1.60 \pm 0.55$ & $\begin{array}{c}0.60 \pm 0.54 \\
t=2.45 \\
p>0.05(N S)\end{array}$ \\
\hline & B & $2.80 \pm 0.45$ & $1.20 \pm 0.45$ & $1.20 \pm 0.45$ & $0.60 \pm 0.55$ & $\begin{array}{c}2.20 \pm 0.45 \\
\mathrm{t}=11.00 \\
\mathrm{p}<0.001(\mathrm{HS})\end{array}$ \\
\hline \multirow[t]{2}{*}{ II } & $\mathbf{A}$ & $2.40 \pm 0.55$ & $2.20 \pm 0.45$ & $1.60 \pm 0.55$ & $1.00 \pm 1.00$ & $\begin{array}{c}1.40 \pm 0.89 \\
\mathrm{t}=3.50 \\
\mathrm{p}<0.05(\mathrm{~S})\end{array}$ \\
\hline & B & $3.00 \pm 0.00$ & $1.20 \pm 0.83$ & $0.60 \pm 0.55$ & $0.20 \pm 0.45$ & $\begin{array}{c}2.80 \pm 0.45 \\
t=14.00 \\
p<0.001(\mathrm{HS})\end{array}$ \\
\hline
\end{tabular}

(NS- Not Significant) 
Table: 6 Statistical analysis of Fever before and after treatment in all groups

\begin{tabular}{|c|c|c|c|c|c|c|}
\hline \multicolumn{7}{|c|}{ FEVER SCORE (Mean \pm SD) } \\
\hline & \multirow{2}{*}{ Groups } & \multirow{2}{*}{$\begin{array}{c}\text { Before } \\
\text { Treatment } \\
\text { (BT) }\end{array}$} & \multicolumn{3}{|c|}{ After Treatment(AT) } & \multirow{2}{*}{$\begin{array}{l}\text { Within the } \\
\text { group } \\
\text { comparison } \\
\text { paired t-test } \\
\text { (BT-F3) }\end{array}$} \\
\hline & & & F1 & F2 & F3 & \\
\hline \multirow[t]{2}{*}{ I } & $\mathbf{A}$ & $2.20 \pm 0.84$ & $2.00 \pm 0.71$ & $1.60 \pm 0.55$ & $1.40 \pm 0.55$ & $\begin{array}{c}0.80 \pm 0.45 \\
\mathrm{t}=4.00 \\
\mathrm{p}<0.05(\mathrm{~S})\end{array}$ \\
\hline & B & $2.80 \pm 0.45$ & $1.20 \pm 0.45$ & $1.00 \pm 0.00$ & $0.80 \pm 0.45$ & -- \\
\hline \multirow[t]{2}{*}{ II } & $\mathbf{A}$ & $2.40 \pm 0.55$ & $1.40 \pm 0.89$ & $1.20 \pm 0.84$ & $0.40 \pm 0.55$ & $\begin{array}{c}2.00 \pm 0.70 \\
t=6.32 \\
p<0.01(H S)\end{array}$ \\
\hline & B & $2.40 \pm 0.89$ & $1.00 \pm 0.71$ & $0.40 \pm 0.55$ & $0.00 \pm 0.00$ & $\begin{array}{c}2.40 \pm 0.89 \\
\mathrm{t}=6.00 \\
\mathrm{p}<0.01(\mathrm{HS})\end{array}$ \\
\hline
\end{tabular}

Total relief in Sign and Symptoms of Cellulitis during treatment

Table: 7 Relief percentages on the signs and symptoms of Cellulitis $(n=20)$

\begin{tabular}{|c|c|c|c|c|c|c|}
\hline \multirow{2}{*}{$\begin{array}{l}\text { Sr. } \\
\text { No }\end{array}$} & \multirow[t]{2}{*}{ Symptoms } & \multirow[t]{2}{*}{ Groups } & \multicolumn{3}{|c|}{ Symptom Score } & \multirow{2}{*}{$\begin{array}{l}\text { \% Decrease in } \\
\text { symptom score } \\
\text { after treatment }\end{array}$} \\
\hline & & & B T & $\mathrm{AT}$ & DIFF. & \\
\hline \multirow[t]{4}{*}{1.} & \multirow{4}{*}{ Pain } & IA & 14 & 8 & 6 & 42.85 \\
\hline & & IB & 15 & 4 & 11 & 73.33 \\
\hline & & IIA & 14 & 5 & 9 & 64.28 \\
\hline & & IIB & 15 & 0 & 15 & 100 \\
\hline \multirow[t]{4}{*}{2.} & \multirow[t]{4}{*}{ Edema } & IA & 15 & 10 & 5 & 33.33 \\
\hline & & IB & 15 & 3 & 12 & 80.00 \\
\hline & & IIA & 15 & 4 & 11 & 73.33 \\
\hline & & IIB & 15 & 1 & 14 & 93.33 \\
\hline \multirow[t]{4}{*}{3.} & \multirow[t]{4}{*}{ Tenderness } & IA & 13 & 7 & 6 & 46.15 \\
\hline & & IB & 15 & 3 & 12 & 80.00 \\
\hline & & IIA & 13 & 6 & 7 & 53.84 \\
\hline & & IIB & 14 & 1 & 13 & 92.85 \\
\hline \multirow[t]{4}{*}{4.} & \multirow[t]{4}{*}{ Erythema } & IA & 11 & 8 & 3 & 27.27 \\
\hline & & IB & 14 & 3 & 11 & 78.57 \\
\hline & & IIA & 12 & 5 & 7 & 58.33 \\
\hline & & IIB & 15 & 1 & 14 & 93.33 \\
\hline \multirow[t]{4}{*}{5.} & \multirow[t]{4}{*}{ Fever } & IA & 11 & 7 & 4 & 36.36 \\
\hline & & IB & 14 & 4 & 10 & 71.42 \\
\hline & & IIA & 12 & 2 & 10 & 83.33 \\
\hline & & IIB & 12 & 0 & 12 & 100 \\
\hline
\end{tabular}




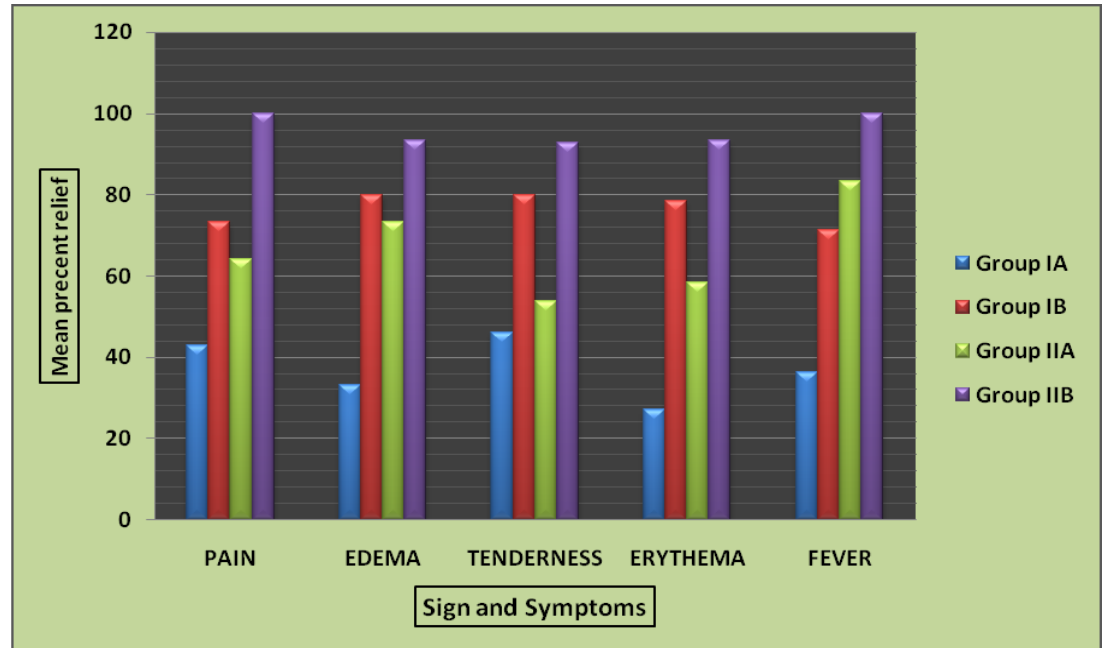

Fig: 1 Total relief in sign and symptoms of cellulitis during treatment with all groups

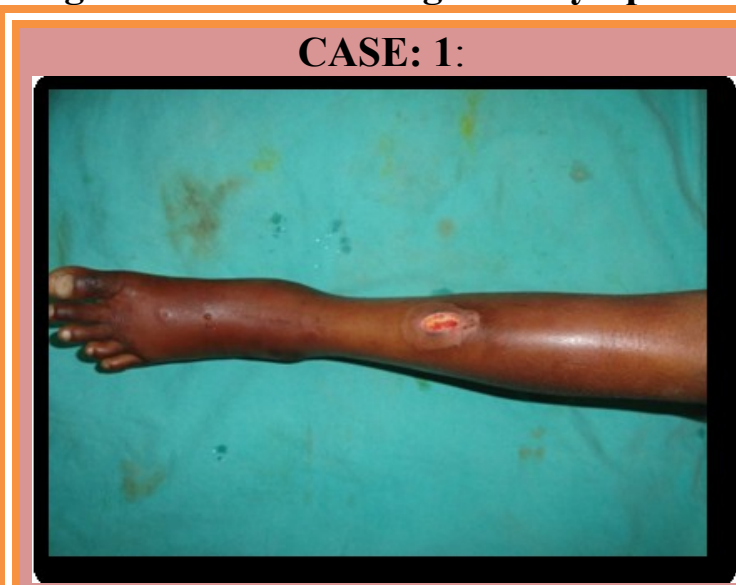

Left leg cellulitis before treatment (Day-0)

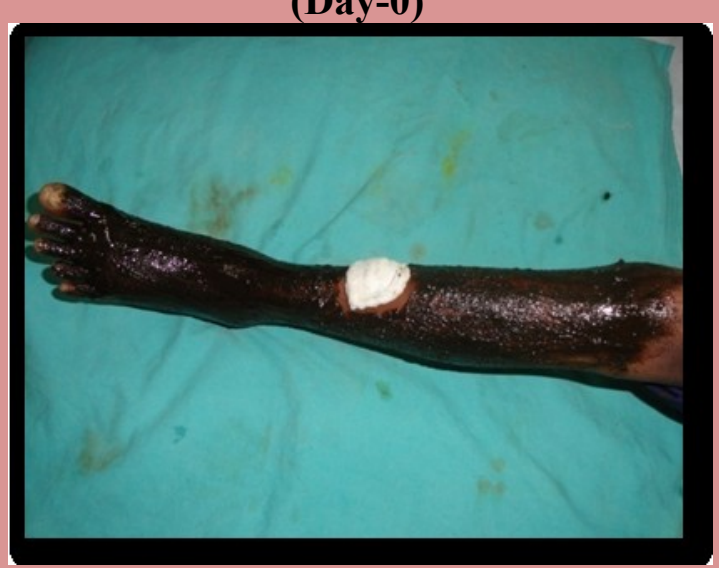

During application of Dashang lepa

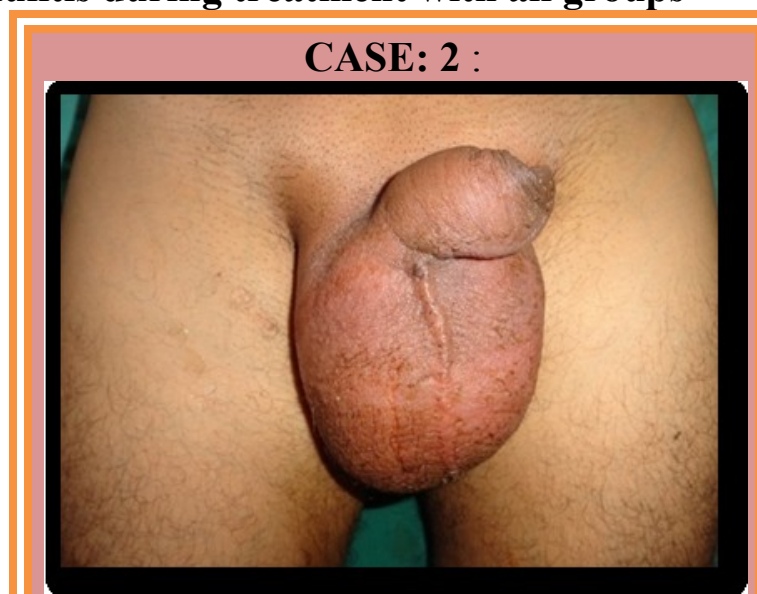

Scrotum cellulitis before treatment (Day-0)

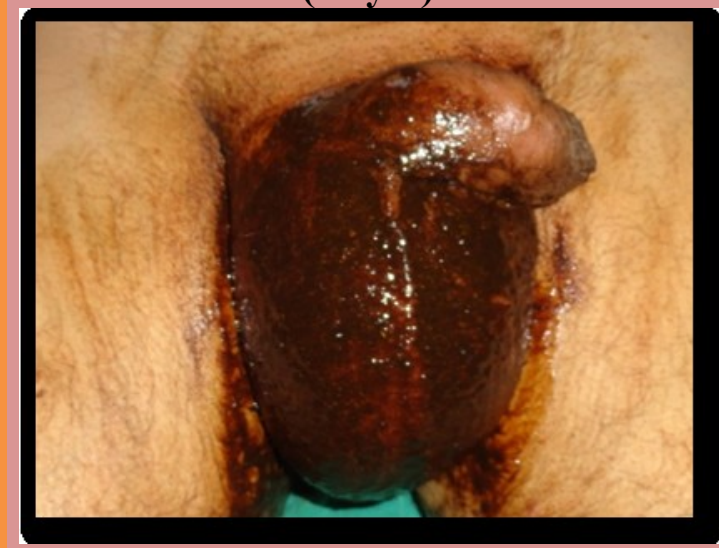

During application of Dashang lepa 

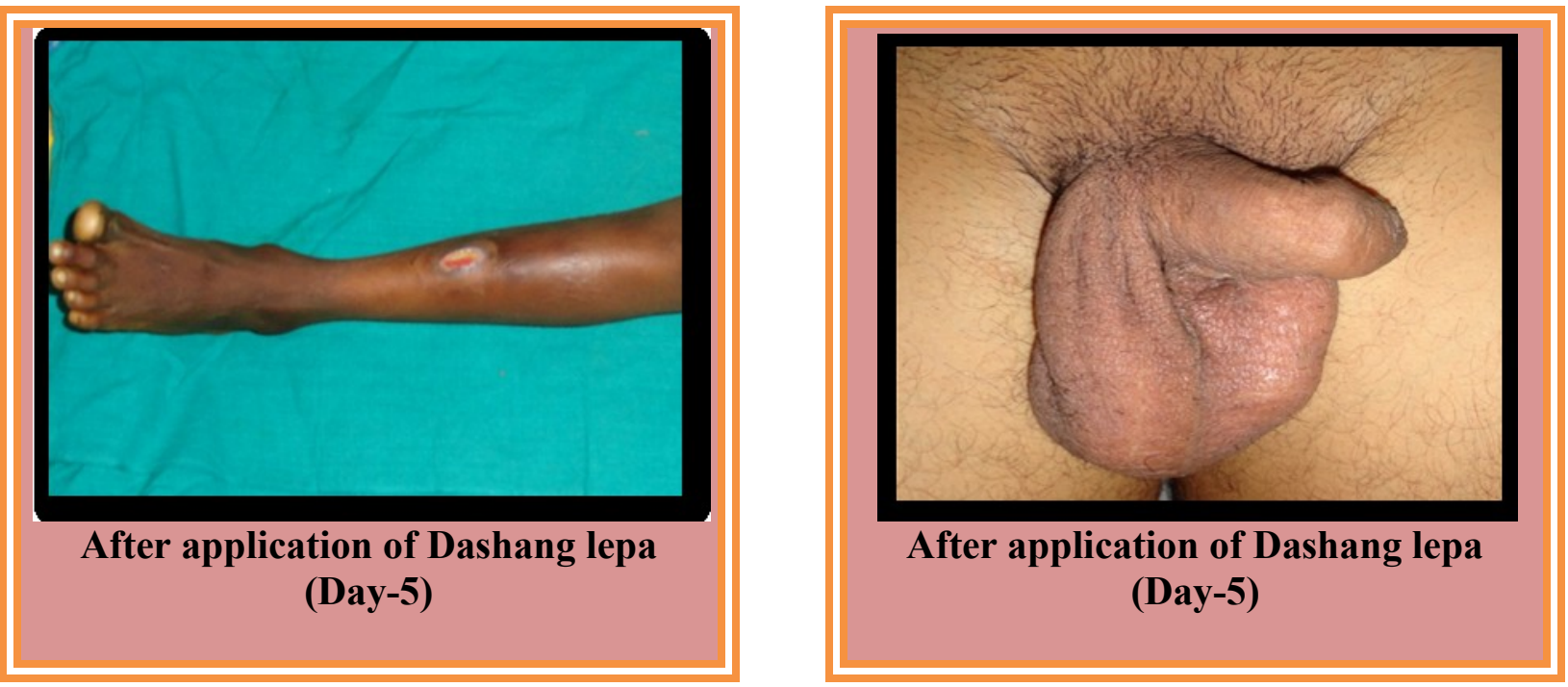

Fig. 2 Application of Dashang Lepa in patients of Cellulitis

\section{Discussion:}

The present study revealed that the Dashang lepa is very effective and statistically highly significant $(\mathrm{p}<0.01)$ in terms of pain. It might be due to decrease in prostaglandin level. This clearly shows this drug contain analgesic properties. Inflammatory edema is reduced which is probably due to Dhatushoshak (absorptive) effect of Kashaya and Tikta Rasa (taste) of most of the drugs in Dashang lepa. It alleviates vitiated Kapha to reduce the edema. Erythema in inflammatory process is due to increase blood supply over injured area due to vasodilation. In present study Dashang lepa has shown statistically highly significant $(\mathrm{p}<0.001)$ in terms of reduction in erythema (redness). This might be due to Pittashamak effect of the drug when apply with cow's pure butter (ghrita). The Kashaya, Tikta rasa and Sheeta Virya have capability to constrict blood vessels, hence it reduces the erythema. Most of the patient showed significant relief and found to be free from toxic effect of disease within 2-3 days of the application of Dashang Lepa. This is probably due to it makes a barrier to superficial of the diseased region when applied with ghrita so can also prevent further invasion of bacteria.

\section{Conclusion:}

Dashang lepa reduces all cardinal features of inflammation as Pain (Dolor), Edema (Tumour), Erythema (Rubor), Tempreture (Calor) in patients of cellulitis. Thus it can be proven as potent antiinflammatory medicine. In present study Dashang lepa was taken with ghrita in 5:1 ratio to form paste and applied lukewarm on affected area according to mentioned in Ayurvedic literature. No adverse reaction was found after topical application of Dashang lepa; hence it is proven safe and to be applying in each age group of patients. It is a preliminary study on Dashang lepa and further research works are going on in experimental model.

\section{Acknowledgement:}

The authors are grateful to Department of Shalya Tantra, Faculty of Ayurveda, Institute of Medical sciences, Banaras Hindu University, Varanasi for giving permission to carry out this study. 


\section{References:}

1. Shastri A, editor. Sushruta Samhita of Sushruta, Ayurvedatatva Sandipika commentary, Part I, Sutrasthan 17/3; Chaukhamba Sanskrit sansthan,Varanasi; 2007, p.70.

2. Fitzpatrick's, Dermatology in General medicine, $5^{\text {th }}$ edition, volume-2, Chapter 197, McGraw-Hill Professional;1999; p. 2214-2229.

3. Eriksson B, Erysipelas: Clinical and bacteriologic spectrum and serological aspects. Clinical infectious Diseases. 1996;23(5): p. 1091-8.

4. Voros D, Role of early and extensive surgery in the treatment of severe Necrotizing soft tissue infection; British J Surg; 1993;80; p.1191.

5. Shashtri R.D, editor. Chakradutta of Chakrapanidutta, Visarpa Visphot Chikitsa: Chapter 52, Verse 32. Varanasi: Chaukhambha Subharti Prakashan, 2006; p. 209.
6. Tripathi B, editor. Sharangdhar Samhita of Sharangdhar, Uttarkhand; Chapter 11, Verse 4-6. Varanasi: Chaukhambha Subharti Prakashan; 2006; p. 391.

7. Mishra BS, editor, $\left(9^{\text {th }}\right.$ ed. $)$. Bhavprakash of Bhavmishra, Part II, Madhyamkhand; Visarpadhikar: Chapter 56, Verse 32. Varanasi: Chaukhambha Sanskrit Bhavan; 2005; p. 551.

8. Shashtri BS, editor. Yogaratnakar of Shashtri LP, Uttarardh; Visarpa Chikitsa: Dashang lepa, Verse 1. Varanasi: Chaukhambha Prakashan; 2009; p. 248.

9. Mishra SN, editor. Bhaishjyaratnavali of Govindas Sen, Part II, Visarprogadhikar: Chapter 57, Verse 18. Varanasi: Chaukhambha Subharti Prakashan; 2007; p. 918. 